\title{
Suppression mechanism study of attached apex drogue on undesirable inflation phenomena
}

JUN LI

DOI: $10.35530 / \mathrm{IT} .069 .02 .1414$

JING YANG

HAN CHENG

\section{REZUMAT - ABSTRACT}

\section{Studiu asupra mecanismului de suprimare a ancorei apex ataşate asupra fenomenului de umflare nedorită}

În prezent, studiile privind efectul de suprimare a ancorei apex ataşate asupra umflării nedorite au fost în mare măsură dependente de experimente. Experimentele au descoperit cu dificultate mecanismul de suprimare din cauza dificultății de colectare a datelor. În această lucrare, a fost propus un model FSI (Fluid Structure Interaction) bazat pe o metodă explicită a elementelor finite pentru a studia mecanismul de suprimare. Metoda grafică de deformare a fost utilizată pentru a realiza mişcarea domeniului computational. În acelaşi timp, condițile de viteză au fost aplicate la limitele domeniului computațional, care a fost utilizat pentru a simula câmpul eolian extern. Cuplajul dintre fluid şi structura descrisă de polinomul de interpolare Lagrange a fost realizat prin algoritmul de contact. în cele din urmă, a fost dezvoltată o paraşută extra mare ca obiect de studiu, iar mecanismul de suprimare a ancorei apex ataşate a fost analizat în funcție de rezultatele numerice. Efectul diferitelor ancore apex ataşate cu diferite caracteristici de rezistenta, a fost, de asemenea, analizat de modelul FSI. Modelul şi metoda de analiză propuse în această lucrare ar putea oferi baza de proiectare a paraşutelor extra mari.

Cuvinte-cheie: țesături fabricate, paraşută extra mare, element finit explicit, metodă numerică, aplicații ale textilelor

\section{Suppression mechanism study of attached apex drogue on undesirable inflation phenomena}

At present, the studies of suppression effect of attached apex drogue on undesirable inflation were seriously dependent on experiments. The experiments were difficult to reveal the suppression mechanism due to the difficulty of data collection. In this paper, a FSI (Fluid Structure Interaction) model based on explicit finite element method was proposed to study the suppression mechanism. The graphical deformation method was used to realize the movement of computational domain. At the same time, the velocity conditions were applied on the boundaries of computational domain, which was used to simulate the external wind field. The coupling between the fluid and structure described by Lagrangian meshes was realized by contact algorithm. Finally, an extra-large parachute was taken as the research object, and the suppression mechanism of attached apex drogue was analyzed according to the numerical results. The effect of different attached apex drogues with different resistance characteristics also was analyzed by the above FSI model. The analysis model and method proposed in this paper could provide the design basis of extra-large parachute.

Keywords: engineered fabrics; extra-large parachute; explicit finite element; numerical method; textiles application

\section{INTRODUCTION}

With the growing of outer space exploration activities of human, more and more countries have developed the extra-large parachutes with nominal area of more than 1000 square meters. However, the extra-large parachutes have larger sizes and longer inflation time than ordinary life-saving parachutes. The undesirable inflation phenomena such as canopy twisting and whipping are more vulnerable to appear before removing the reefing line, and these phenomena may cause failure of recovery. The most typical example is the fourth airdropping experiments of Mars probe's parachute system in the United States in 2004, and there were two failed recovery because of the canopy whipping.

However, a large number of engineering experiments have proved that the attached apex drogue can effective suppress the undesirable inflation phenomena [1]. In fact, the attached apex drogues were generally used in American Appollo spacecraft, the Russian Soyuz spacecraft and the Chinese Shenzhou space- craft. But the studies about suppression effect of attached apex drogue were mostly based on experiments and the related theoretical and numerical studies were less. Wang applied a multistage, multi element and multi freedom dynamic model to study the suppression effect of attached apex drogue, but the suppression mechanism based on FSI was not proposed [1]. Zhang used CFD/MSD (Computational Fluid Dynamics/Mass Spring Damper) coupling model to study the effect of attached apex drogue on inflation process, but this model was only suitable for twodimensional calculation and couldn't simulate canopy twisting and whipping. In addition to the CFD/MSD model, there have other FSI models such as DSD/SST (Deforming Spatial Domain/Stabilized Space Time) model, IB (Immersed Boundary) model and ALE (Arbitrary Eulerian Lagrangian) model can be used to study parachute's opening process [2-5]. But most of the above models and methods used the fixed computational domain. If those models were used to calculate the parachute's airdropping process, the calculation amount would be larger and the 
calculation time would be longer. In addition, those models and methods ignored the effect of external wind field.

In order to explain the suppression mechanism from FSI mechanics perspective, the finite element meshes were used to describe the parachute-load system and flow field and the coupling calculation was realized by contact algorithm. Meanwhile, the graphical deformation method was applied to realize the movement of computational domain and reduce the calculation amount. The external wind field was also taken as velocity conditions and applied on the boundaries of computational domain. Based on the above model, the suppression mechanism of attached apex drogue was studied and the effect of different attached apex drogues with different resistance characteristics was also analyzed in this paper.

\section{MATERIALS AND METHODS}

In this paper, the finite element method was used to simulate the pre-inflation process of an extra-large parachute before removing the reefing line. The finite elements could track the material boundary well, therefore the mass conservation was satisfied naturally and only the momentum conservation equation was needed to solve:

$$
\begin{aligned}
& \int_{\Omega} B_{I j} \sigma_{j i} \mathrm{~d} \Omega-\left(\int_{\Omega} N_{I} \rho b_{i} \mathrm{~d} \Omega+\int_{\Gamma_{t_{i}}} N_{I} \bar{t}_{i} \mathrm{~d} \Gamma\right)+ \\
+ & \delta_{i j} \int_{\Omega} N_{I} N_{J} \rho \mathrm{d} \Omega \dot{V}_{J i}=\boldsymbol{f}^{\text {int }}-\boldsymbol{f}^{\text {ext }}+\boldsymbol{M a}=0
\end{aligned}
$$

where, $B_{I j}=\frac{N_{I}}{x_{j}}, N_{I}$ - shape function, $\sigma$ - stress, $\rho$ - density of materials, $f^{\text {int }}-$ internal force matrix, $\boldsymbol{f}^{\text {ext }}$ - external force matrix, $\boldsymbol{M}$ - mass matrix and $a$ - acceleration matrix.

The central difference scheme was applied in time marching:

$$
\begin{aligned}
\boldsymbol{v}^{n+\frac{1}{2}}=\boldsymbol{v}^{n-\frac{1}{2}} & +\Delta t^{n} \boldsymbol{M}^{-1}\left(\boldsymbol{f}^{\mathrm{ext}}\left(\boldsymbol{d}^{n}, t^{n}\right)-\boldsymbol{f}^{\mathrm{ext}}\left(\boldsymbol{d}^{n}, t^{n}\right)\right)= \\
& =\boldsymbol{v}^{n-\frac{1}{2}}+\Delta t^{n} \boldsymbol{M}^{-1} \boldsymbol{f}^{n}
\end{aligned}
$$

Both the flow field and parachute-load system were based on Lagrangian description, therefore the coupling calculation between the two could be transformed into contact calculation based on penalty function algorithm. Meanwhile, in order to simulate the permeability of fabrics, the Ergun equation was applied to calculate the coupling force $f_{\text {couple }}$ which was taken as a part of external force $f^{\text {ext }}$ in eqn. 1 [6].

In figure 1 , the external wind field was taken as velocity conditions applied on the flow field boundaries. Meanwhile, the graphical deformation method was used to realize fluid meshes' moving to reduce the calculation amount. Three noncollinear nodes were selected randomly on load elements shown in figure 1 . The coordinates of these nodes are $x_{\mathrm{A}}, x_{\mathrm{B}}$ and $x_{\mathrm{C}}$. Then a local coordinate could be defined and was given as:

$$
\begin{aligned}
& x^{\prime}=\left(x_{\mathrm{B}}-x_{\mathrm{A}}\right) /\left|x_{\mathrm{B}}-x_{\mathrm{A}}\right| \\
& z^{\prime}=x^{\prime}\left(x_{\mathrm{C}}-x_{\mathrm{A}}\right) /\left|x^{\prime}\left(x_{\mathrm{C}}-x_{\mathrm{A}}\right)\right| \\
& y^{\prime}=z^{\prime} \times x^{\prime}
\end{aligned}
$$

In each time step, the local coordinate would move followed the load. The transformation matrix $T$ can be obtained by before and after the displacement of load meshes [7]. Therefore, the new homogeneous coordinate of each node can be obtained and was given as:

$$
\left[\begin{array}{llll}
x_{1}^{*} & x_{2}^{*} & x_{3}^{*} & 1
\end{array}\right]=\left[\begin{array}{llll}
x_{1} & x_{2} & x_{3} & 1
\end{array}\right] \cdot \boldsymbol{T}
$$

Here, $\left[\begin{array}{llll}x_{1}^{*} & x_{2}^{*} & x_{3}^{*} & 1\end{array}\right]$ is the homogeneous coordinate after moving and $\left[\begin{array}{llll}x_{1} & x_{2} & x_{3} & 1\end{array}\right]$ is that before moving. Then the convection velocity $c(\hat{v}=\Delta x / \Delta t, c=v-\hat{v})$ which took the flow field meshes as reference can be calculated. Then, the fluid velocity was replaced by convection velocity $c$.

After the fluid meshes distorted on each time step, the reconstructed fluid meshes was obtained by solving the Laplace differential equation and updated the flow field information by MUSCL (monotone upwind schemes for conservation laws) scheme [8].

Here, an extra-large parachute [2, 9] with nominal area of 1200 square meters was taken as the research object and the structure parameters were shown as follow in table 1 . The structure parameters of attached apex drogue were shown in table 2.

It could be found in airdropping experiment that the attached apex drogue has completely inflated before the main parachute's inflation, and this paper only studied the pre-inflation process [9]. Therefore, the effect of attached apex drogue could be replaced by mechanical boundary applied on 96 nodes (figure 2) and the force of each node $F_{\text {node }}$ was given as:

$$
F_{\text {node }}=\frac{1}{2} \cdot \rho_{\text {air }} \cdot v^{2} \cdot C A / n_{\text {belt }}
$$

Here, $v$ is the velocity of parachute-load system, $C A$ - the resistance characteristic of attached apex drogue, and $n_{\text {belt }}$ - the number of reinforced belts.

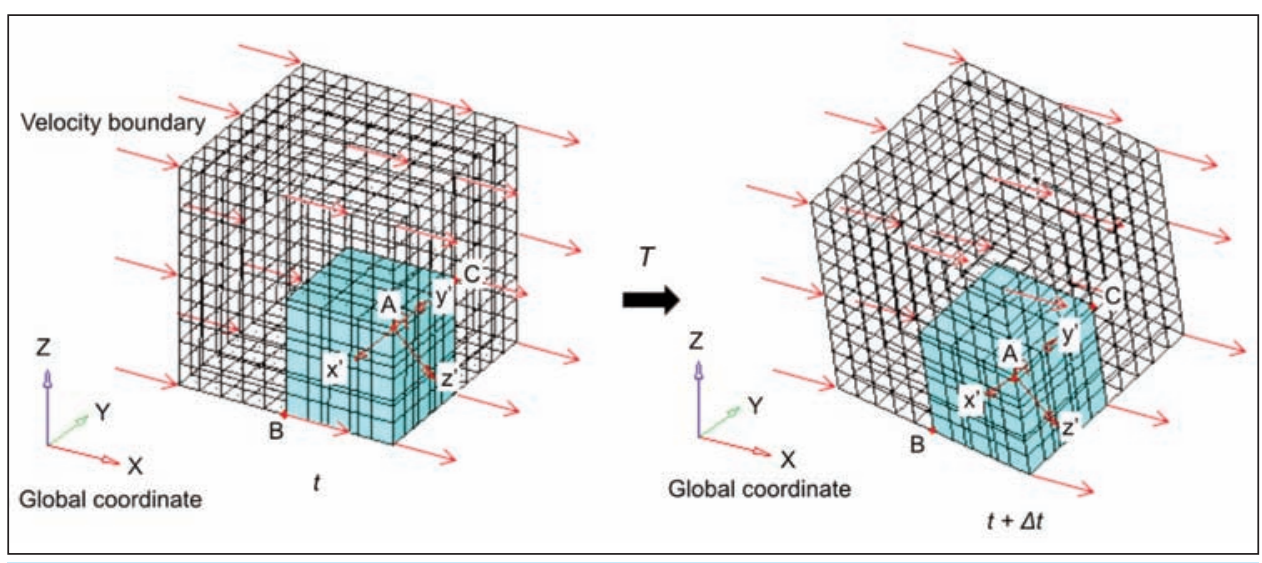

Fig. 1. Fluid meshes' motion (the cyan meshes represent load elements, the wireframe meshes represent fluid elements, and red arrows are velocity boundary) 
STRUCTURE PARAMETERS OF MAIN PARACHUTE

\begin{tabular}{|c|c|}
\hline Type of parachute & Ringsail parachute \\
\hline Number of canopy gores & 96 \\
\hline Number of rings & 8 \\
\hline Number of sails & 12 \\
\hline Nominal area $\left(\mathrm{m}^{2}\right)$ & $1.2 \mathrm{E}+3$ \\
\hline Nominal diameter $(\mathrm{m})$ & 39.09 \\
\hline Length of line $(\mathrm{m})$ & 49.2 \\
\hline Mass of payload $(\mathrm{kg})$ & $3.4 \mathrm{E}+3$ \\
\hline
\end{tabular}

Then according to the structure parameters of main parachute, the meshes model was established on real scale (figure 2). The lines and canopy were completely straightened, and the connection point of lines was fixed with load. The first four rings on the canopy top were meshed by quadrilateral shell elements $(6,528)$, the rest of the canopy were meshed by triangle elements $(85,440)$, and the reinforce belts and lines were by bar elements $(31,400)$. The fluid field was described by a cube $(50 \mathrm{~m} \times 50 \mathrm{~m} \times 74 \mathrm{~m})$, and was meshed by hexahedral meshes $(2,052,000)$. In this paper, the coupling between parachute-load system and fluid was realized by contact algorithm, therefore it didn't need to establish the complicated body fitted meshes. Both the structure and fluid meshes interpenetrated with each other.

The rings and sails of canopy were made in polyamide grid silk, the lines and reinforced belts

\begin{tabular}{|c|c|}
\hline \multicolumn{2}{|c|}{$\begin{array}{c}\text { STRUCTURE PARAMETERS OF ATTACHED } \\
\text { APEX DROGUE }\end{array}$} \\
\hline Type of parachute & $\begin{array}{c}\text { Rib-less guide } \\
\text { surface parachute }\end{array}$ \\
\hline Number of canopy gores & 12 \\
\hline Resistance characteristics $\left(\mathrm{m}^{2}\right)$ & 0.8 \\
\hline Length of connecting belt $(\mathrm{m})$ & 5 \\
\hline Length of line $(\mathrm{m})$ & 1.58 \\
\hline
\end{tabular}

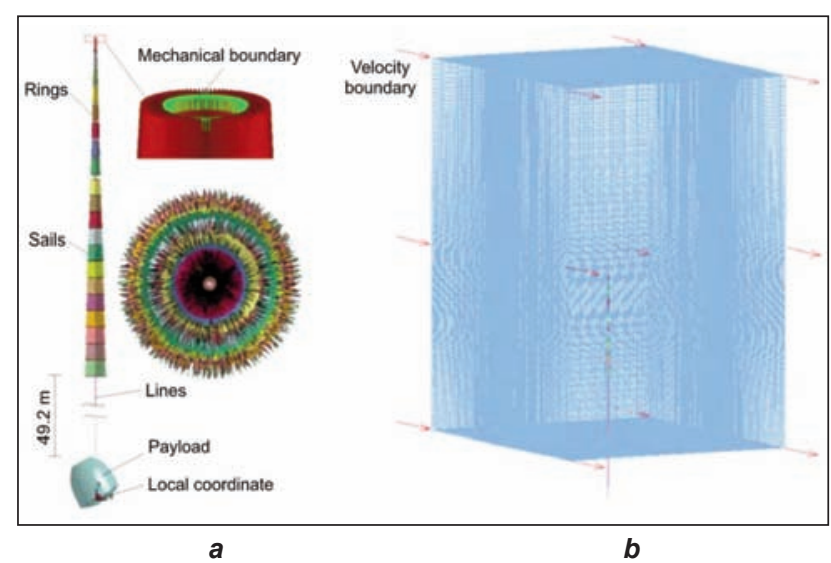

Fig. 2. Finite element model ( $a$ - canopy, lines and payload; $b$ - parachute and fluid field)

were made in flame-retardant polyamide rope. And the material properties and initial working conditions were according to practical engineering (table 3 ).

Table 3 Figure 3 shows the pre-inflation RESULTS AND DISCUSSION

\begin{tabular}{|c|c|c|}
\hline \multicolumn{3}{|c|}{ MATERIAL PROPERTIES AND INITIAL WORKING CONDITIONS } \\
\hline \multirow{5}{*}{$\begin{array}{l}\text { Material properties } \\
\text { of rings }\end{array}$} & Density $\left(\mathrm{kg} / \mathrm{m}^{3}\right)$ & 479 \\
\hline & Young's modulus $(\mathrm{Pa})$ & $7.3 E+8$ \\
\hline & Thickness $(\mathrm{m})$ & $1 \mathrm{E}-4$ \\
\hline & Linear resistance coefficient $\left(\mathrm{kg} / \mathrm{m}^{3} \cdot \mathrm{s}\right)$ & $1.03 \mathrm{E}+6$ \\
\hline & Quadratic resistance coefficient $\left(\mathrm{kg} / \mathrm{m}^{4}\right)$ & $4.5 \mathrm{E}+5$ \\
\hline \multirow{5}{*}{$\begin{array}{c}\text { Material properties } \\
\text { of sails }\end{array}$} & Density $\left(\mathrm{kg} / \mathrm{m}^{3}\right)$ & 512 \\
\hline & Young's modulus $(\mathrm{Pa})$ & $4.3 E+8$ \\
\hline & Thickness $(\mathrm{m})$ & $1 \mathrm{E}-4$ \\
\hline & Linear resistance coefficient $\left(\mathrm{kg} / \mathrm{m}^{3} \cdot \mathrm{s}\right)$ & $1.1 \mathrm{E}+6$ \\
\hline & Quadratic resistance coefficient $\left(\mathrm{kg} / \mathrm{m}^{4}\right)$ & $1 \mathrm{E}+6$ \\
\hline \multirow{3}{*}{$\begin{array}{c}\text { Material properties } \\
\text { of lines }\end{array}$} & Density $\left(\mathrm{kg} / \mathrm{m}^{3}\right)$ & 462 \\
\hline & Young's modulus $(\mathrm{Pa})$ & $9.7 E+10$ \\
\hline & Diameter of line $(\mathrm{m})$ & $3 \mathrm{E}-3$ \\
\hline \multirow{3}{*}{$\begin{array}{l}\text { Material properties } \\
\text { of reinforced belts }\end{array}$} & Density $\left(\mathrm{kg} / \mathrm{m}^{3}\right)$ & 462 \\
\hline & Young's modulus $(\mathrm{Pa})$ & $9.7 E+10$ \\
\hline & Breadth $(\mathrm{m})$ & $1 \mathrm{E}-2$ \\
\hline \multirow{2}{*}{ Properties of air } & Density $\left(\mathrm{kg} / \mathrm{m}^{3}\right)$ & 0.57 \\
\hline & Ambient Pressure $(\mathrm{Pa})$ & $4.2 \mathrm{E}+4$ \\
\hline \multirow{3}{*}{$\begin{array}{l}\text { Initial working } \\
\text { conditions }\end{array}$} & Velocity of parachute-load system $(\mathrm{m} / \mathrm{s})$ & 100 \\
\hline & Contrail declining angle $\left({ }^{\circ}\right)$ & 90 \\
\hline & Velocity of horizontal lateral wind field $(\mathrm{m} / \mathrm{s})$ & 5 \\
\hline
\end{tabular}
processes of Model A (without attached apex drogue) and Model $B$ (with attached apex drogue). It could be found in figure 3 , a that both Model A and Model B were inflated from canopy bottom firstly. The air mass couldn't reach the canopy top instantly and formed the 'bottleneck' phenomenon, due to the larger nominal area. With the air entering the canopy, a symmetric vortex began to form in the external flow field and move from canopy bottom to top. At the same time, it could be found that the vortex structure in windward area was weaker than that in leeside. With the continuous decelerating of parachute-load system, the canopy of Model A would no longer keep straight state due to the inertia force and the lack of effective constraints (figure $3, b$ ). The canopy top of Model A began to appear relaxed state. And the top part began to twist and whip under the external air flow, which 


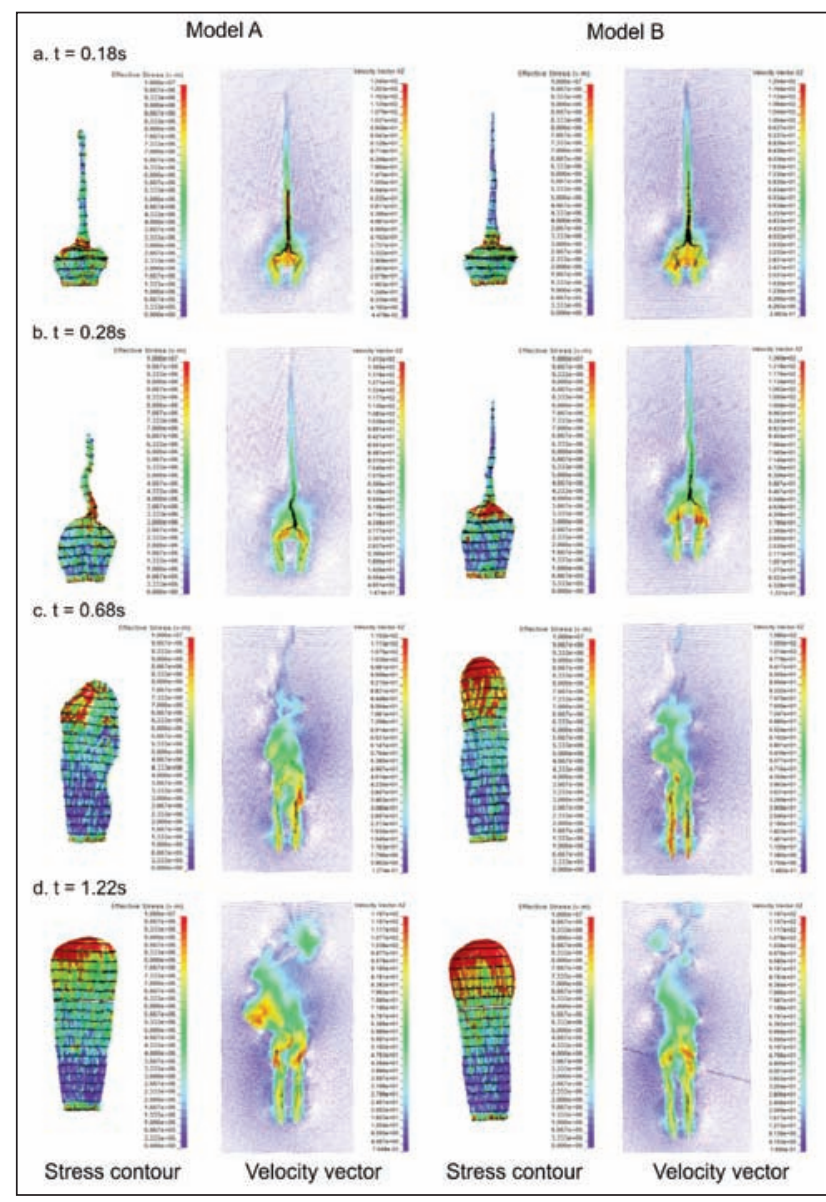

Fig. 3. Numerical results of pre-inflation processes

caused asymmetric inflating. The stress of 'bottleneck' part of Model A presented an asymmetric distribution. The above undesirable inflation phenomena caused the inflation process of Model $A$ was slower than Model B. In contrast, the Model B remained a straight state by the effects of constraining force from the attached apex drogue. It could be found that there were no undesirable inflation phenomena during inflating, but the 'bottleneck' phenomenon still existed on Model B. The vortexes of Model A and B began to develop into more complicated and smaller

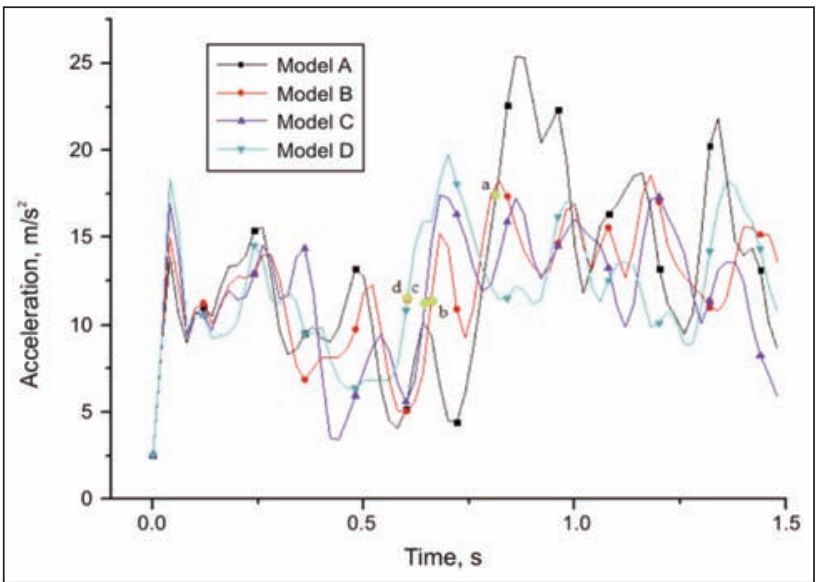

Fig. 4. Acceleration of payload (the green points labeled lowercase letter denote the beginning of fully inflation stage of four models) and gradually separated from the canopy in an asymmetric way.

From figure 3,c, it could be found that Model B inflated faster than Model A by the effect of attached apex drogue. The 'bottleneck' phenomenon of Model A and B disappeared after the 'bottleneck' moved to the canopy top and the vent was completely opened. The vents completely opened could signal the start of fully inflation stage. With more and more air into the canopy, both Model A and Model B began to expand from the top part the bottom. Finally, the canopies would remain as shown in figure $3, d$ because of the constraint of the reefing lines. After the formation the effective aerodynamic deceleration area, the vortexes shedding phenomenon was further aggravated. In this paper, the pre-inflation processes of different models with different resistance characteristics (the resistance characteristic of Model $C$ and $D$ were $1.0 \mathrm{~m}^{2}$ and $1.15 \mathrm{~m}^{2}$ respectively) also were calculated by the above method and the 'bottleneck' phenomena also were found in these results. The 'bottleneck' caused the deceleration effect even weakened in pre-inflation processes, which was different from the ordinary life-saving parachutes (figure 4). But the attached apex drogues avoided the appearance of undesirable inflation phenomena (Model B/C/D), which made the time of vents' opening earlier than Model $A$. It also could be found in figure 4 that the bigger the resistance characteristic, the earlier the fully inflation beginning. In addition, the attached apex drogues were helpful to reduce the overload, and had a good protective effect on the parachute-payload system.

It was worth noting that the canopy body of Model B would be more slender after the vent was completely opened because of the top constraints (figure 3,c and $d$ ). And the aerodynamic deceleration area of Model B was smaller than Model A before removing the reefing line. Therefore the deceleration effect of Model A was more obvious than others after the vent was completely opened. While the other three models had little difference in velocity changes shown in figure 5 .

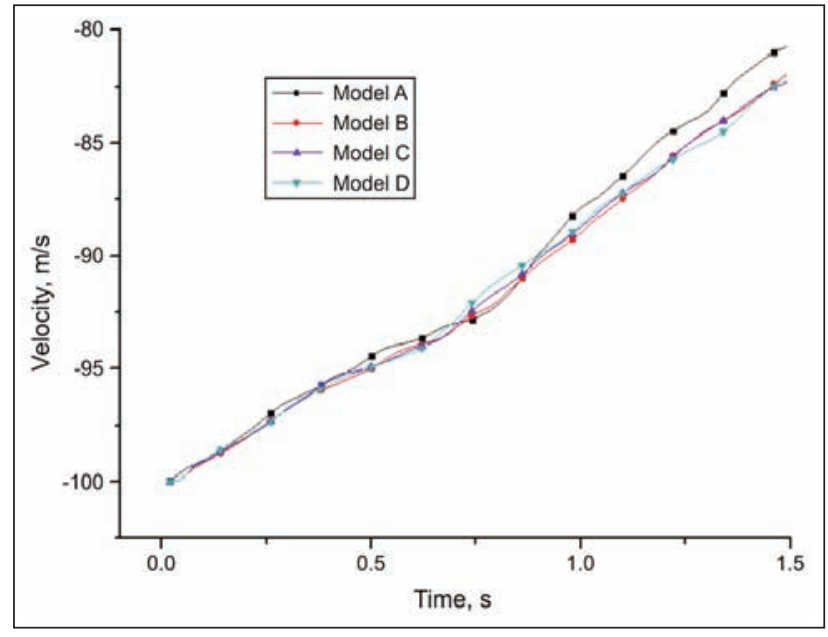

Fig. 5. Velocity of payloads 

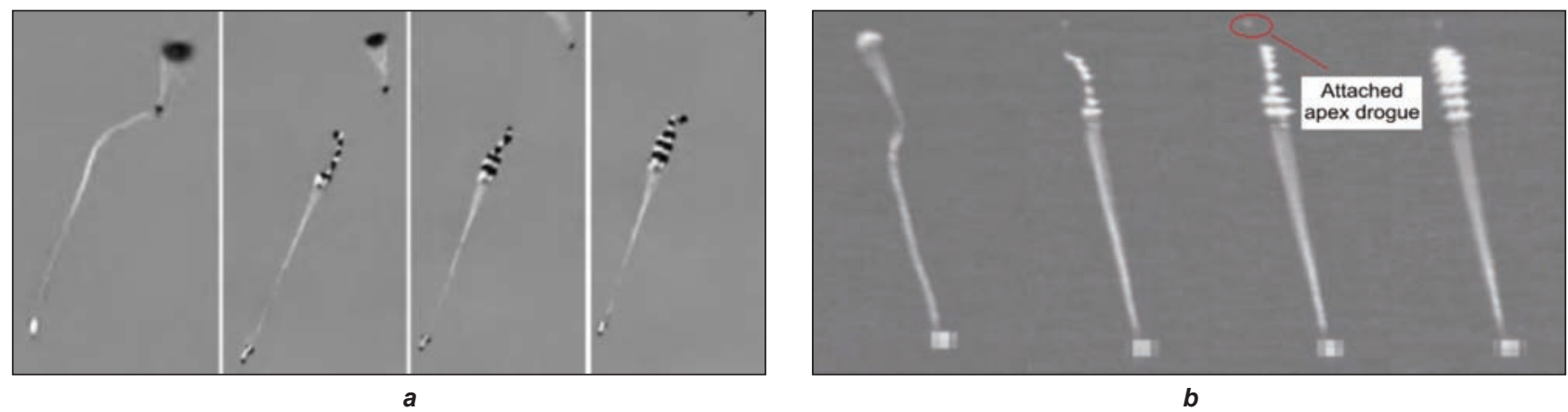

Fig. 6. Airdrop experiment: $a$ - without attached apex drogue; $b$ - with attached apex drogue [9]

The corresponding airdrop experiments also proved the suppression effect of attached apex drogue [9]. The serious whipping was found in the pre-inflation process of the parachute without the attached apex drogue (figure $6, a$ ), while there were no undesirable inflation phenomena in figure $6, b$. The 'bottleneck' phenomenon also was found in the actual airdropping experiment, which was the same as the numerical results in this paper.

\section{CONCLUSIONS}

In this paper, the fluid structure interaction method based on explicit finite element model was used to calculate the inflation process before removing the reefing line, and the abundant information of flow field and structure were obtained. By analyzing these numerical results, it was found that the effective top constraints were the key to prevent the appearance of undesirable inflation phenomena. In addition, the suppression effect of different attached apex drogues with different resistance characteristics was analyzed by the same numerical method. The method in this paper could provide a basis for the design and optimization of extra-large parachute system.

\section{ACKNOWLEDGMENTS}

This paper is supported by National Natural Science Foundation of China (No. 11602293) and Civil Aviation Flight Technology and Flight Safety Research Base (No. F2015KF03).

\title{
BIBLIOGRAPHY
}

[1] Wang, H.T., Qin, Z.Z., Song, X.M., Guo, P. Effects of the attached apex drogue on phenomenon of bull whipping in the deployment process of large parachute, In: Journal of National University of Defense Technology, 2010, vol. 21, no. 4, pp, 49-54.

[2] Zhang, H.Y., Qin, F.D., Liu, W.H., Tong, M.B. Effects of attached apex drogue in main parachute inflation process, In: Journal of Nanjing University of Aeronautics and Astronautics, 2010, vol. 42, no. 1, pp. 47-51.

[3] Tezduyar, T.E., Behr, M., Liu, J. A new strategy for finite element computations involving moving boundaries and interfaces: the deforming-spatial-domain/ space-time Procedure: I. The concept and the preliminary numerical tests. In: Computer Methods in Applied Mechanics and Engineering, 1992, vol. 94, no. 3, pp. 339-351.

[4] Kim, Y.S., Peskin, C.S. 3-D Parachute simulation by the immersed boundary method, In: Computers and Fluids, 2009, vol. 38, pp. 1080-1090.

[5] Tutt, B.A., Taylor, A.P. The use of LS-DYNA to simulate the inflation of a parachute canopy, In: AIAA Report, 2005-1608, 2005.

[6] Cheng, H., Zhan, Y.N., Yang, X., Yu, L., Chen, X. Numerical study of the permeability effect on parachute working process, In: Industria Textila, 2014, vol. 65, no. 6, pp. 329-334.

[7] Bao, H.J., Jin, X.G., Peng, Q.S. Basic algorithms of computer animation, Zhejiang University publishing house, 2000.

[8] Souli, M., Ouahsine, A., Lewin, L., ALE formulation for fluid-structure interaction problems. In: Computer methods in applied mechanics and engineering, 2000, vol. 190, pp. 659-675.

[9] Rong, W., Gao, S.Y., Li, J. The deceleration strategy and reliability validation of the parachute system on the Shenzhou spacecraft. In: Science China Technological Sciences, 2014, vol. 33, no. 3, pp. 251-260.

\author{
Authors: \\ JUN LI ${ }^{1}$, HAN CHENG ${ }^{2}$, JING YANG ${ }^{1}$ \\ ${ }^{1}$ Nanchang Institute of Technology \\ 330044, Jiangxi Nanchang, China \\ ${ }^{2}$ Civil Aviation Flight University of China, Aviation Engineering Institute \\ 46 Nanchang Road 618307, Sichuan Guanghan, China
}

Corresponding author:

HAN CHENG

e-mail: chenghanstorm@sina.com 